\title{
Mixed Land Use in Delhi: Impact on Infrastructure and Environment and Suggestions for Sustainable Planning
}

\author{
Nidhi Bindal ${ }^{1 *}$, Swati Talwar ${ }^{2}$ \\ ${ }^{1}$ Pearl Academy, New Delhi 110011, India \\ ${ }^{2}$ Central Public Works Department, New Delhi 110011, India \\ Corresponding Author Email: email.nidhibindal@gmail.com
}

https://doi.org/10.18280/ijsdp.160719

Received: 23 May 2021

Accepted: 1 September 2021

\section{Keywords:}

mixed-use, sustainability, environmental impact, infrastructure planning, urban planning, master plan

\begin{abstract}
Mixed-use has been a part of our cities since historic times where retail, workshop, etc. all coexisted with the residence. Industrialization and associated adverse impacts led to overtaking of mixed-use concept by zoning. However, the ills of segregation started showing in the cities, and urban planners, sociologists and anthropologists started advocating in favor of reintroducing mixed-use. Now it is being planned worldwide to attain vibrant and cohesive urban development. Despite the well-established benefits of mixed-use, the Master Plan of Delhi's approach of increasing the ambit of 'permitting' mixed-use as against the strategy of 'planned mixed-use development' adopted in other global cities makes us question the likely impacts of this liberal shift. Thus the study aims at investigating the environmental implications of such mixed-use development in the city of Delhi. From the assessment of two case study areas, it can be inferred that the nature and magnitude of impact on a mixed-use area is determined by the type of mix and its intensity, for example, in Lajpat Nagar numerous retail establishment led to vehicle-related issues while in Naraina the issues were infrastructure-related due to type of activities. It was recommended that the policies guiding the mixed-use development are in dire need of a mechanism to assess the impacts, identify demand-supply gaps and future needs, and thereafter augment accordingly to mitigate the implications in a case-specific manner.
\end{abstract}

\section{INTRODUCTION}

\subsection{Background}

Most medieval towns and cities show emergence of mixed use commercial and residential happening in the same geographical area. Industrialization and associated decay of city forced planners to segregate use to improve the living conditions of the urban citizen. However, soon the ills of segregation could be realized and emerged a need of relooking at the city planning. In this context, Mixed Land Use became one of the most propagated urban planning principles having origin in Jane Jacob's critic of segregation of land use in her phenomenal work The Death and Life of Great American Cities. Jacob notices that 'Fine grain mixing of diverse uses create vibrant and successful neighborhood' [1]. Many scholars have since then researched on various aspects of mixed land use which resulted in design concepts like New Urbanism, Smart Growth and Transit Oriented Development etc. [2-4]. Mixed use in a city is also linked to environmental quality, equity and efficiency of post-industrial city [5].

Depending on the scale of land, different types of mixeduse typologies can occur ranging from mix of uses at building level to a cluster of buildings. The various typologies and mix possibilities led to numerous definitions for the concept of mixed-use in the field of land use planning. David Rhind in his book discusses how the same piece of land can have two or more uses which can be incidental to each other in various combinations and give this the terminology mixed land use
[6]. Karen et al describe land use mix as heterogeneous pattern of land use in geographically specified zones and typically including residential, commercial, institutional, industrial, recreational, and agricultural uses [7]. Explaining the characteristics of a good land use, Murrain explains 'Good mixed-use can be defined as a finely grained mix of primary land uses, namely a variety of housing and workplaces with housing predominant, closely integrated with all other support services, within convenient walking distance of the majority of the homes' [8]. The definition provided by the Adelaide city council seems to cover almost all the possibilities of mixeduse concept 'Development which comprises a mixture of two or more land uses, either comprised within a single building (horizontally or vertically) or multiple buildings of different uses within a distinct development site' [9].

In the case of Delhi land use planning was introduced in 1962 with the first master plan of Delhi [10] which followed a segregated zoning-based land use policy. The mixed-use regulation was a quick response to prevent sealing and demolition of thousands of illegal/ unauthorized commercial establishments in residential areas as per the Supreme Court Order in 2006 [11]. With such unplanned mixed use development, it becomes important to verify the presumed advantages associated with mixed land use planning.

\subsection{Need and importance of the study}

There are various benefits of mixed-use as discussed by various authors like compactness and pedestrian friendly [12] 
environmentally sustainable [13], social cohesion, urban vitality $[14,15]$, realizing the social capital [16], etc. Grant notes that by providing housing near commercial and civic activities, planners could reduce the dependency of the elderly and children on cars; Enabling people to live near places where they can shop, work, or play could reduce car ownership and vehicle trips, increase pedestrian and transit use, and thus alleviate the environmental consequences associated with automobile use' [13].

However, the benefits of mixed use cannot be simply presumed. As Wardner correctly pointed out, 'mixed-use can be handled by the planning policy up to a point only' [3] and needs sincere efforts and favorable conditions to achieve the desired impact. There are many studies pointing out the illeffects of the same due to bad planning or poor implementation etc. Bahadure and Kotharkar in their study tried to specify the proportion of mix of compatible uses to create a sustainable environment in Nagpur. 'The study revealed that neighborhoods with high and moderate land-use mix are sustainable with travel behavior while high and low mix are not as sustainable' [17]. Ghosh highlights the problems associated with unplanned mixed use, 'Non-planned or converted mixed use (residential buildings which are later used for commercial/ institutional purposes) cause additional problems as they are not designed for such uses and lack the required infrastructure or maintenance system thereby becoming nuisance for the residents' [18]. In case of Delhi, Mahajan points out how mixed use became a driver of poor living conditions because of the focus being on real estate for private gain. Mahajan notes 'Instead of achieving the expected social and environmental objectives, mixed use has acted as a catalyst for real estate development purely for private gain' [11]. These studies clearly highlight the issues that may arise if mixed use is not planned or implemented in the right spirit, and hence, there needs to be a constant measuring of positive and negative impacts of the mixed land use on the urban environment. While many studies measure the impact of mixed use on transit [12], urban vitality [14] etc., there was almost no literature available on infrastructural stress and pollution which are important aspects of planning sustainable neighborhoods. Hence, this study tries to focus on the environmental implications of the mixed land use developments in Delhi by taking case of two zones converted from residential to mixed use and analyzing the impact on them.

\subsection{Literature review of mixed land use in Delhi}

In case of Delhi the phenomena of mixed use existed since pre independence times in old areas like Shahjahanabad. However, in 1962 with the first master plan; the city was introduced with the concept of zoning and thereby discontinuing mixed uses. With two subsequent master plans, the policy has seen a shift from permitting existing mixed uses as an acceptance of need for the society to planning mixed use as a part of proposed land use plan in the new areas (Table 1).

As can be seen in the comparison above, Master plan of Delhi (MPD) has changed from strict segregation of uses in 1962 to conversion of existing single use lands to mixed use in 2001 , to including provisions for planning the mixed use in 2021. The policy over the 3 MPD's has had many additions in the MLU provisions.

Table 1. Comparative of mixed use in various Master Plans of Delhi (MPD)

\begin{tabular}{|c|c|c|c|}
\hline & 1962 & 2001 & 2021 \\
\hline $\begin{array}{l}\text { Population in } \\
\text { proposal year }\end{array}$ & $1961=2.6$ million & $1991=9.42$ millions & $2011=16.7$ millions \\
\hline $\begin{array}{c}\text { Projected } \\
\text { Population } \\
\end{array}$ & & $2001=13$ million & $2021=23.0$ millions \\
\hline Area & $1487 \mathrm{Sq} . \mathrm{Km}$. & $1487 \mathrm{Sq} . \mathrm{Km}$. & $1487 \mathrm{Sq} . \mathrm{Km}$. \\
\hline $\begin{array}{l}\text { Perspectives } \\
\text { on mixed use }\end{array}$ & $\begin{array}{l}\text { Defines present conditions of } \\
\text { mixed use as undesirable } \\
\text { with examples like residential } \\
\text { and shopping. } \\
\text { In case of industries; cites as a } \\
\text { source of nuisance and is } \\
\text { more concerned with living } \\
\text { environment. }\end{array}$ & $\begin{array}{l}\text { In the situation, where in a number of } \\
\text { residential areas, commercial activity } \\
\text { has already intruded formulation of a } \\
\text { balanced policy of mixed use } \\
\text { considering its environmental impact } \\
\text { and socio-economic need of society is } \\
\text { of utmost public importance. }\end{array}$ & $\begin{array}{l}\text { Acknowledges the need for permitting mixed } \\
\text { land use and lays down the conditions for } \\
\text { implementation. } \\
\text { The over-riding principles for permitting mixed } \\
\text { use - need to acknowledge and make adequate } \\
\text { provision for meeting community needs, } \\
\text { mitigating environmental impact \& providing } \\
\text { for safe and convenient circulation \& parking. }\end{array}$ \\
\hline \multirow{4}{*}{$\begin{array}{l}\text { Provisions } \\
\text { for mixed use }\end{array}$} & $\begin{array}{l}\text { Resettlement of industries in } \\
\text { residential areas. }\end{array}$ & \multirow{4}{*}{$\begin{array}{l}\text { Declaration of Mixed Land Use streets } \\
\text { after traffic assessment \& demand } \\
\text { assessment on municipal services. } \\
\text { The following activities shall not be } \\
\text { allowed: Retail shops of building } \\
\text { material, firewood, coal. Repair shop } \\
\text { and nursing homes, guest houses, } \\
\text { storage, godowns, junk shops, } \\
\text { fabrication and welding. }\end{array}$} & $\begin{array}{l}\text { Declaration after assessment of existing } \\
\text { nonresidential activity \& demand on } \\
\text { amenities. }\end{array}$ \\
\hline & $\begin{array}{l}\text { Removal of village like } \\
\text { activities (Dairy, Pottery } \\
\text { etc.) }\end{array}$ & & $\begin{array}{l}\text { Mixed use permissible, } \\
\text { in residential premises: commercial, public- } \\
\text { semipublic and professional activity. }\end{array}$ \\
\hline & $\begin{array}{l}\text { Permits incidental uses like } \\
\text { nursery, clinics and other on } \\
\text { special permission. }\end{array}$ & & $\begin{array}{l}\text { Retail shops shall be permitted on plots } \\
\text { abutting streets notified for mixed use only } \\
\text { on the ground floor up to the maximum } \\
\text { permissible ground floor coverage. }\end{array}$ \\
\hline & $\begin{array}{l}\text { Discontinuance of non- } \\
\text { confirming uses }\end{array}$ & & $\begin{array}{l}\text { Nursing homes, guest houses, banks were } \\
\text { now permitted to } 100 \% \text { of FAR in certain } \\
\text { areas. }\end{array}$ \\
\hline
\end{tabular}


It is assumed that mixed use would reduce ridership and transport use by residents to meet their daily needs. Cervero in his study confirms the decrease of transit ridership in the areas surrounding the Transit-Oriented Development (TOD) zones whereas an increased ridership in the TOD zone [19]. However, this cannot be generalized as mixed use developments are complex with varied mix of use possible, different population densities, infrastructural planning etc. Specifically, in case of Delhi, mixed use was introduced in a non-planned manner to cater to the public outcry to save the various establishments running on a land use earmarked for a different purpose in masterplan.

\subsection{Aims and objectives}

Even though mixed-use has many advantages regarding cohesive neighborhoods and the potential of being a tool for sustainable development, yet if not planned properly, has the potential to cause environmental stress.

With an intent to make mixed land use more sustainable in terms of resource use, this study aims to investigate the environmental implications of mixed-use development and thereafter suggest measures to mitigate the adversities.

To determine environmental implications, one needs to examine the policy provisions and its inherent implications and associated impacts on ground. To achieve the same, the following objectives have been defined:

To assess environmental implications of mixed-use developments in Delhi.

To recommend environmental conscious measures to deal with identified issues (if any) of the mixed land use in Delhi.

\subsection{Scope and limitations}

Despite all sincere attempts to complete the study in all regards, this study achieves the aims with certain limitations.

a) The scope of mixed land use is restricted to mix of non-residential activities permitted in residential premises.

b) The study focuses on the physical urban environmental aspects and thus social, biotic, and economic implications are not part of the study.

c) The study will be limited to two stretches in Delhi due to time constrain and convenience.

d) The study looks at only unplanned mixed-use areas (i.e. areas declared mixed-use later on due to various reasons). This is done as Delhi as an urban center is fully developed and there is little scope of developing mixed-use areas from the scratch.

e) Proposals will be in the form of recommendations only due to the lack of extensive data required as mixed-use has diverse possibilities.

\subsection{Methodology}

The paper used both quantitative and qualitative methods to achieve the aim and to arrive at the outcomes. Literature study comprising of Master Plan documents [10, 20, 21], planning policies, scholarly research on the topic was done to understand the concept of mixed land use in the city of Delhi, and to understand the prevailing policy provisions in terms of its scope. To assess the growth the case study method was adopted. Two sites were identified for which land use data was available in scholarly researches, and present-day data was obtained through physical survey by authors. The growth pattern was analyzed by doing comparative analysis and was mapped to the changing planning norms and policy changes. To conduct the assessment of 'environmental implications of mixed-use developments' parameters were identified on the basis of literature study of policy planning documents of cities worldwide and parameters of environmental assessment used in general. Identified parameters were clubbed under two heads, i.e., Infrastructure (water, wastewater, solid waste, electricity) and Pollution (air and noise).

Environmental implications of infrastructure parameters were assessed by doing a comparative study of two scenarios. Scenario 1 assumes the case study area to be completely single-use i.e. residential while scenario 2 is mixed-use as exiting on site. The standards for infrastructure demand/consumption were taken from various manuals like CPHEEO [22] while the extent of mixed-use and nature of use were derived from the primary survey.

The assessment of pollution was done through indirect/implied means. Since the scope of mixed use was limited to residential to commercial, it was assumed that the highest impact on pollution is through the vehicular pollution. Hence, the amount of change in pollution was determined by taking into account standards of vehicular emissions and numbers of vehicles associated with the use premises. Number of vehicles also was observed to be an indirect indicator for air and noise pollution.

Comparative study of assessment parameters in two scenarios, combined with analysis of pattern and growth of mixed-use for two case study areas led to identification of issues, associated reasons and stress points for environment.

Literature studies of planning documents for cities across the globe were again referred to arrive at recommendations relevant in addressing/mitigating the identified environmental implications.

\section{CASE STUDIES}

\subsection{Selection of case study areas}

Areas for case study were selected such that one could see a difference in terms of use premises (activities), location in the city, nature of the area (planned, rehabilitation, unauthorized etc.). The scale of the study area was restricted to a single street as the Master Plan of Delhi notifies mixeduse 'streets' based on the percentage of mixed-use existing on them. Also, paucity of time was a factor because of which the study is limited to one street each in two areas of Delhi. A street each in the neighborhoods of Lajpat Nagar and Naraina was selected.

Lajpat Nagar is a planned rehabilitation colony. The site was planned as residential, declared mixed-use in the MPD 2001 while the 2006 notification declared it as commercial which is a direct indication of growth of nonresidential activity in the residential area. The major characteristic of the site is its location and proximity to nonhierarchical city level market which needs to be considered while looking at the environmental implications. The original plot sizes planned were 167.2 sq.m. \& 250.8 sq.m. which have now undergone subdivision and commercialization.

In contrast, Naraina Vihar is a post-independence planned plotted development. The selected street i.e. Ch. Girdarilal 
Goswami Marg $40 \mathrm{~m}$ wide. It is the main road connecting ring road and the Patel road and acts as an outer road to residential areas with total 72 plots varying in sizes from 167.2 sq.m. \& 718.2 sq.m.

\subsection{Study parameters}

Both the selected areas were studied on various parameters to understand the growth in mixed use and resultant impact on the environment. The data was collected and analyzed to reach at certain observations and conclusions. The identified parameters were -

1. The pattern of Growth - This was done to identify how much area has changes from residential to mixed use.

2. The nature of Growth - It was important to understand if all mixed use result in the same infrastructural stress and pollution levels, or if there could be a difference based on the kind of sub-use category. Hence, the nature of growth of mix was mapped to understand the sub category of use.

3. Infrastructure Stress - It was understood through literature review that land use was proposed in the first place as the infrastructural requirements including water, sewage, waste, electricity etc. were different for different uses. Hence, it was important to understand how much impact it creates on infrastructure when one land use changes to other as was the case with Delhi.

4. Pollution - One of the biggest criteria of assessing sustainable development is to judge the pollution generated. Hence, data was analyzed to understand the change in pollution levels before and after mixed use in the two selected case study areas.

After identifying the change in growth pattern, infrastructural requirements and pollution levels, attempt was made to qualify the growth under various sub use categories to further understand the reason behind the difference in impact. This could help propose a policy for allowing mixed use taking into account the needs and requirements of every sub use category.

\subsection{Assessment}

\subsubsection{The pattern of growth}

The changing nature of the two stretches was recorded in terms of number of plots converting to mixed land use and pattern of change was analyzed. It was observed that the development was moving towards mixed use in both the study areas, with a demonstrable increase of $10 \%$ in Lajpat Nagar and $3 \%$ in Naraina in 5 years (Table 2 and Table 3 ).

Table 2. Growth pattern change in Lajpat Nagar

\begin{tabular}{c|c|c}
\hline & $\mathbf{2 0 0 8}$ & $\mathbf{2 0 1 3}$ \\
\hline Total No. of Plots & 112 & 126 \\
\hline Plots with Non-residential activity & 31 & 58 \\
\hline Commercialization/Mixed Use & $28 \%$ & $46 \%$ \\
\hline
\end{tabular}

Table 3. Growth pattern change in Naraina Vihar

\begin{tabular}{c|c|c}
\hline & $\mathbf{2 0 0 8}$ & $\mathbf{2 0 1 3}$ \\
\hline Total No. of Plots & 72 & 72 \\
\hline Plots with Non-residential activity & 32 & 34 \\
\hline Commercialization/Mixed Use & $44 \%$ & $47 \%$ \\
\hline
\end{tabular}

This clearly implies that mixed land use has increased in residential neighbourhoods at a rapid pace and needs proper planning so that the benefits of mixed use could be achieved without compromising on the factors of resident safety, urban environment, and sustainable development etc.

\subsubsection{The nature of growth}

The use data for two years namely 2008 and 2013 was recorded for both the stretches and analysed (Figure 1 and Figure 2). Observations were made on the percentage of change in mixed use along with identification of the category of the use.

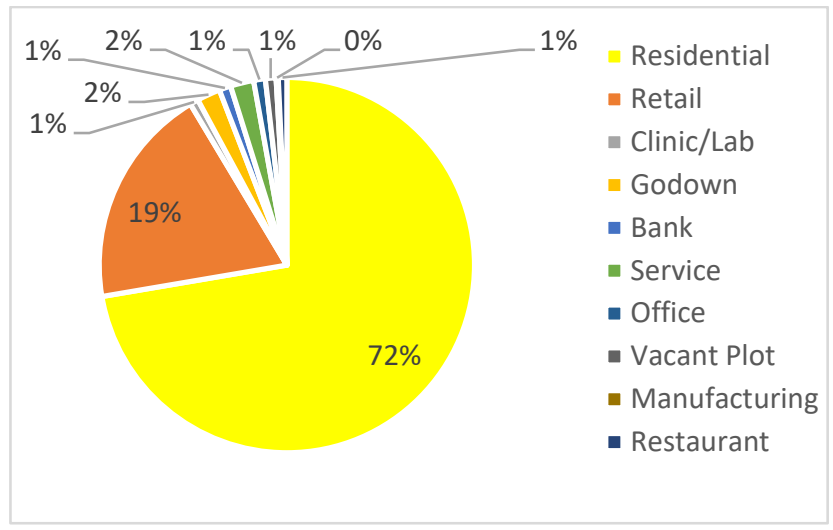

Figure 1. Land use for Lajpat Nagar in 2008

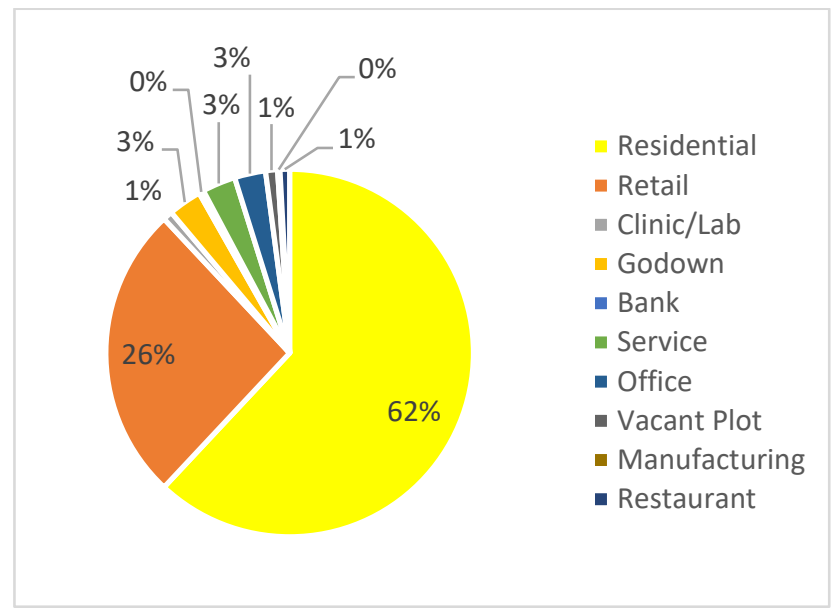

Figure 2. Land use for Lajpat Nagar in 2013

It was observed that there was not a varied mix of uses that increased, but on the contrary a big increase in retail activity, from $19 \%$ to $26 \%$ was recorded. The market in Lajpat Nagar named as Central market grew from a local shopping area to a zonal shopping zone to a sub city level market. An increase in number of similar use premises (retail of garments and accessories in this case) lead to widening in the catchment of the site. The proximity to existing sub city level shopping center was identified as one of the major factors for continuing growth of retail and support activities. This implies that location plays a critical role in determining the type of growth and its characteristics. Also, it was observed that the commercial activity increase was not equal for all sub use categories and for Lajpat Nagar the growth was much more in retail shops. This high increase of retail activity was of limited use for the daily needs of residents who still needed to travel outside the neighbourhood for their other needs like medical and education. 


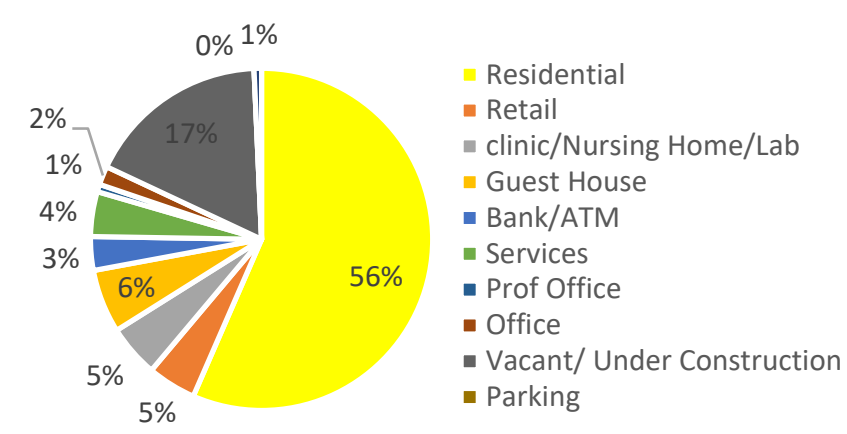

Figure 3. Land use for Naraina Vihar in 2008

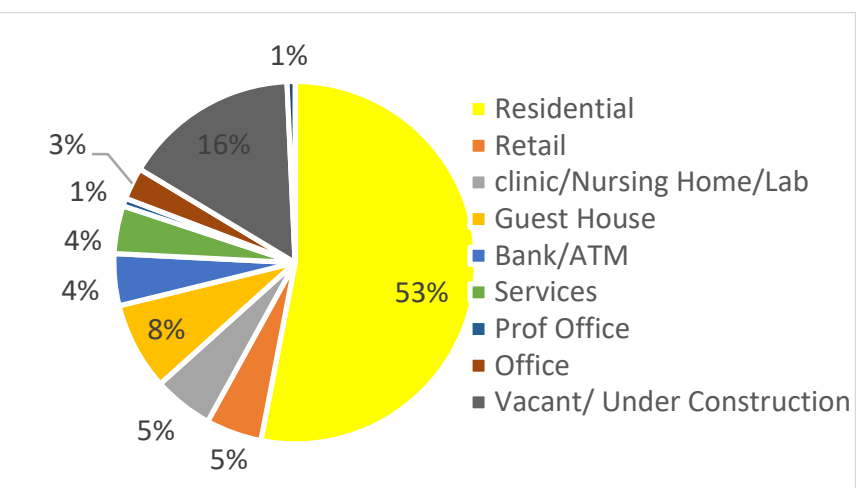

Figure 4. Land use for Naraina Vihar in 2013

Also, it was observed that there was a growth in illegal activities as an increase in number support uses like godowns and bottled water manufacturing units that are not permitted under norms was recorded. In the absence of earmarked areas catering to the daily needs of residents, the daily use shop moved to the inner lanes. It is evident through this example that in the absence of control restrictions, mixed-use will continue to penetrate inside residential neighborhoods thereby disturbing the nature of residential areas. Hence, with the introduction of mixed use, it is crucial to also have clear guidelines and checking mechanisms in place to keep it a healthy mix benefiting both the city and the neighbourhood.

Naraina Vihar study area being a planned neighbourhood has defined zones for commercial activities and also have comparatively bigger plot sizes ( $312 \mathrm{Sq}$. m. average). It is observed that there is reduction in residential use premises
(Figure 3 and Figure 4), indicating increase in mixed use yet clear dominance of one type of non-residential activity is not seen. Presence of designated commercial centers caters to the basic needs of the residents, which lead to growth of activities which cater beyond the neighbourhood, like automobile showrooms and guest houses. The growth of these activities is also attributed to the plot sizes convenient for such activities and connectivity to arterial ring road.

It is inferred that once mixed use activities start in an area, they are bound to increase in absence of any control mechanism, the nature of activities are resultant of access, existing activities and plot sizes. The nature of mixed use activities have no relationship with the demand of the neighbourhood and have catchment beyond the immediate neighbourhood thus defying the purpose of reducing travel. It is thus imperative to have a mechanism to control the number as well as type of mixed use activities permitted.

\subsubsection{Infrastructure stress - solid waste, water, wastewater \& electricity}

As explained in methodology section, the study considered two scenarios; Scenario one is the way it is existing today at the time of the study; and scenario two where the whole area was assumed to be residential which used to be the case earlier. For understanding infrastructural demand for scenario 1, the data was referred from various standards, the numbers of use premises and their categories (example retail, nursing home, etc.) were taken from the literature and primary survey for both the case study sites. Then demand for existing infrastructure was calculated as scenario 1 . For scenario 2, all existing use premises were considered residential.

Assessment of infrastructure stress indicator (Refer Table 4) 'Solid waste' demonstrates more than 50\% increase in mixed use scenario for both case study areas. In Lajpat Nagar there is $54 \%$ increase while Naraina had $85 \%$ increase. Increase in quantity leads to demand for more land for disposal, thereby creating indirect stress on land resource. Qualitative aspect of solid waste (Refer Figure 5) is also an environmental concern as waste generated by non- residential activities have more percentage of non-biodegradable and non-recyclable content, thus needing specific disposal strategies and simply cannot be managed theway residential waste is managed.

Assessment of infrastructure stress indicator 'Energy' (Table 4) (measured through electricity consumption) brings to light that consumption for commercial uses is approximately 3 times more as compared to residential. Higher energy demand directly implies more carbon emissions.

Table 4. Change in infrastructure stress due to mixed-use

\begin{tabular}{|c|c|c|c|c|c|}
\hline \multirow[t]{2}{*}{ Infrastructure } & & \multicolumn{2}{|c|}{ Lajpat Nagar } & \multicolumn{2}{|c|}{ Naraina Vihar } \\
\hline & & $\begin{array}{c}\text { Scenario } 2 \text { (full) } \\
\text { Residential }\end{array}$ & Scenario 1 Mixed-use & $\begin{array}{c}\text { Scenario } 2 \text { (full) } \\
\text { Residential }\end{array}$ & $\begin{array}{l}\text { Scenario } 1 \text { Mixed- } \\
\text { use }\end{array}$ \\
\hline \multirow{2}{*}{ Solid Waste } & (kg/day) & 1234 & 2710 & 661.5 & 4549 \\
\hline & $\%$ increase & & $54 \%$ & \multicolumn{2}{|c|}{$85 \%$} \\
\hline \multirow{2}{*}{ Water } & (L/day) & 286870 & 308475 & 145125 & 156710 \\
\hline & $\%$ increase & & $-8 \%$ & \multicolumn{2}{|c|}{$7 \%$} \\
\hline \multirow{2}{*}{ Waste Water } & (L/day) & 229496 & 246780 & 125368 & 116100 \\
\hline & $\%$ increase & & $-8 \%$ & \multicolumn{2}{|c|}{$7 \%$} \\
\hline \multirow[t]{2}{*}{ Electricity } & & $\begin{array}{c}3-10 \mathrm{kwh} / \mathrm{m}^{2} \\
\text { per month for } \\
\text { commercial (offices) }\end{array}$ & $1 \mathrm{Kwh} / \mathrm{m}^{2}$ per month for residential & $\begin{array}{c}3-10 \mathrm{kwh} / \mathrm{m}^{2} \\
\text { per month for } \\
\text { commercial } \\
\text { (offices) }\end{array}$ & $\begin{array}{l}1 \mathrm{Kwh} / \mathrm{m}^{2} \text { per } \\
\text { month for } \\
\text { residential }\end{array}$ \\
\hline & $\%$ increase & & $200 \%$ & \multicolumn{2}{|c|}{$200 \%$} \\
\hline
\end{tabular}




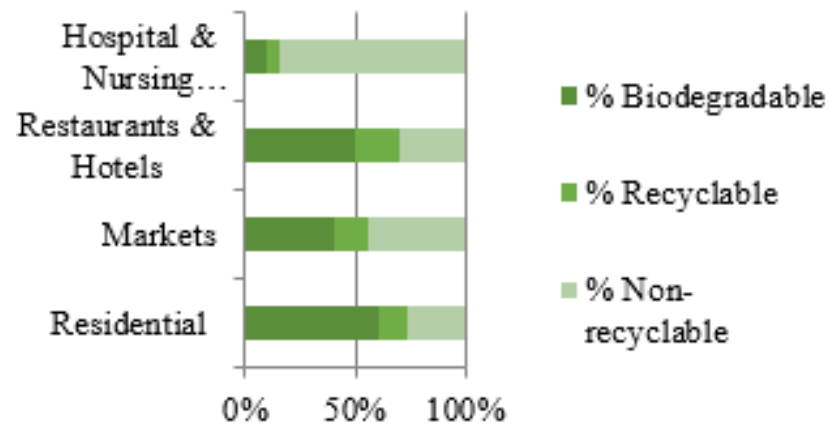

Source: CPEEHO Manual [23]

Figure 5. Characterisation of solid waste

Assessment of infrastructure stress indicator 'Water and wastewater demand' depicts two different situations. In Lajpat Nagar where non residential activities were more retail oriented, the water demand in mixed use scenario is found to be $8 \%$ lower than in all residential scenario. While in case of Naraina the water demand is higher by $7 \%$ in mixed use scenario. The reason behind increase in one infrastructure demand while reduction in other is attributed to the fact that all activities have different per capita demand for water and have different standards for per day waste generations. The retail activity has less per capita water demand as compared with a residential unit or a guest house or a nursing home. The fact that Lajpat Nagar has more quantum of retail activities lead to less water demand while Naraina had water consuming activities like guest houses in the 'mix' thus more water demand.

\subsubsection{Pollution- air and noise}

Air Pollution. The major source of pollution emission was considered as vehicular pollution which accounted for $90 \%$ of the pollution in residential and commercial areas. CPCB's study on air pollution \& source allocation for the city of Delhi has accounted vehicles to be one of the major sources along with industries for polluting the air [24]. The change in number of vehicles was mapped in the two scenarios of mixed use visà-vis fully residential, and the resultant pollutants were recorded and compared (Figure 6).

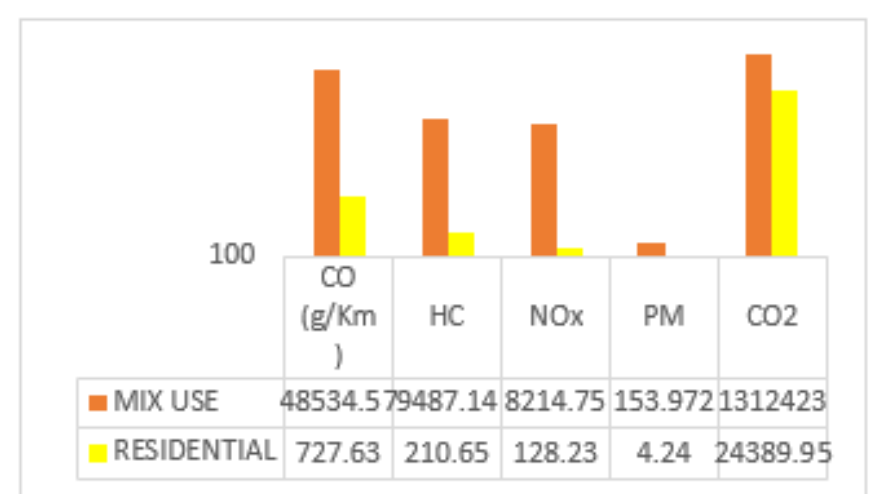

Data Source: Authors based on CPCB report [24]

Figure 6. Pollution emissions at Lajpat Nagar based on vehicle count

A considerable increase of $35 \%$ in Particulate Matter levels, $44 \%$ in Hydrocarbon levels, $52 \%$ in Carbon dioxide levels, $63 \%$ in nitrogen oxide and $65 \%$ was in levels of carbon monoxide was observed in case of mixed use as compared to residential. It is quite evident that mixed-use activity witnesses high air pollutants primarily due to more number of vehicles.

Noise Pollution. In a similar approach as air pollution, the calculation of noise pollution were based on CPCB report [23]. Noise levels were mapped in two scenarios, i.e., mixed use visa-vis fully residential (Figure 7). The noise levels were also mapped at different times of the day. It was observed that in a residential area the noise levels were high all through except during morning \& night hours, owing to maximum vehicular movement in those hours whereas in a mixed-use area we can see the combined effect of noise throughout the day. This indicates that there will be prolonged exposure to high noise levels for comparatively longer hours which is dangerous for the human ear as compared to short durations of high noise levels.

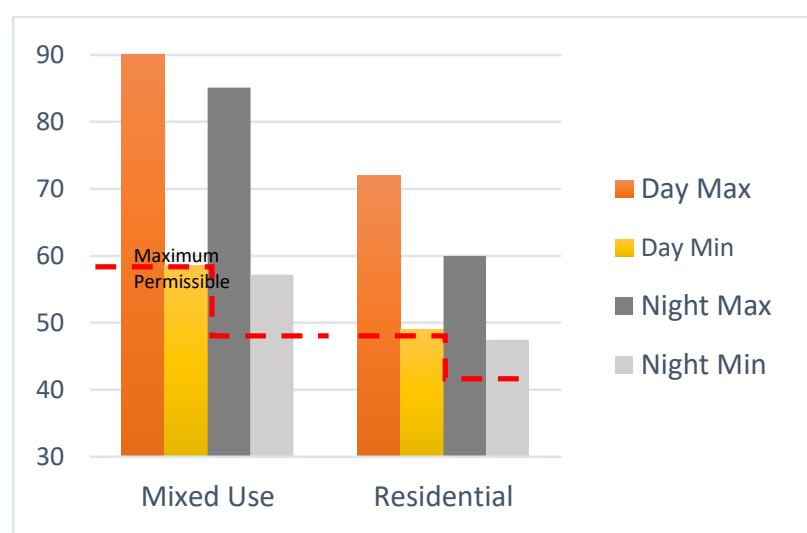

Data Source: CPCB [23]

Figure 7. Noise level in mixed use and residential

It is clearly evident that mixed use neighborhoods have considerably higher pollution - both air and noise - owing to higher level of activity in the area. If it is marginal increase, it could be ignored as the social benefits of mixed use are many, but much higher pollution levels would end up creating health issues for the residents making it unfit for living in the long run. Hence, the change in pollution with the change of use should be predicted and efforts should be made to minimize the impact.

\section{RECOMMENDATIONS}

Gazette notification dated 14 July 2015 [10] provides for mix use in case of redevelopment \& new development, while leaving out the existing one. The recommendations in this paper are thus concentrated on existing mixed use streets.

It is inferred that nature and magnitude of impact on a mixed use area is determined by the type of mix uses and their quantum; which in turn is a factor of accessibility, context, plot sizes and requirement of the area. Thus 'one size fits all' solutions won't do justice to the problem at hand. Hence the twofold recommendations.

First, a methodology to assess stress indicators be developed. The methodology should monitor demand -supply gap, develop a threshold for services \& pollution levels. The assessment should then be used to augment before shortfall and plan for future or restrict growth accordingly. For example, in case of water supply in Naraina, the present scenario demand is higher than its supply. Thus, supply needs to be augmented immediately before permitting more non- 
residential establishments.

Second, a need based calculation of the requirements for the area to be done in terms of type and quantum. Based on this calculation a control mechanism has to be developed to prevent random and undesirable growth. For example MPD 2021 [21] provides for minimum 1 primary school of area 2000-4000 Sqm for a neighbourhood population of 10,000, similarly a need based maximum cutoff for commercial activities in residential areas should be worked out to confine the random growth

One of the prime objectives of mixed use development is to meet the local needs. Therefore, it is not enough to provide spaces just in terms of sqm area. One needs to plan for the type of activities required by the area and also control their numbers too. For example, activities like an automobile showroom in a residential neighborhood (buying a car is not considered a daily need) or say 10 liquor shops in the neighborhood market, permitted under the ambit of mixed development defy the purpose of mixed use serving as a tool for sustainable and inclusive urbanization.

\section{CONCLUSIONS}

Mixed-use development has existed in our historic cities, prevails today, and is being planned for future development. Undoubtedly it is a tool for sustainable development as it ensures optimum utilization of 'land' resource and reduces travel distances; leading to a reduction in fuel emissions thereby promoting low carbon development. On the other hand, the mixed-use development has the potential to cause environmental implications in terms of infrastructure stress, air \& noise pollution, and other issues like possibility of vehicular congestion hindering movement of an emergency vehicle. The environmental implications of mixed use were observed in the analysis of two case study areas. The solid waste demand saw an increase by minimum 54\% in case of mixed use while energy consumption for commercial activities is noted to be $3 \%$ more than residential. The increase in number of vehicles in a mixed use scenario were linked to increase in air pollution levels while noise pollution levels were found to be high throughout the day in a mixed us scenario. Water demand saw a rise by $7 \%$ in Naraina while it saw a similar drop in Lajpat Nagar. It can be said that not all activities will have same impact thus it becomes crucial to develop a methodology to assess overall impact and then develop mitigation strategies accordingly. Adequate infrastructure has an important role in resident satisfaction, and hence planning for a more adequate mix becomes very important for a long term sustainable city planning.

The prevailing planning policies and new 'transit-oriented development' [25] policy guidelines have dealt in depth with the spatial and urban design aspect of 'Mixed-use' while the aspect of environmental implications has a mere mention.

In order to make mixed land use a true 'sustainable' planning tool, one needs to integrate methods to assess possible environmental and infrastructural implications of the various 'mix' to be able to propose the right mix suitable for a particular zone.

\section{REFERENCES}

[1] Jacobs, J. (1961). The Death and Life of Great American
Cities. New York: Random House.

[2] Hirt, S. (2007). The mixed-use trend: Planning attitudes and practices in Northeast Ohio. Journal of Architectural and Planning Research, 24(3): 224-244.

[3] Wardner, P. (2014). Explaining mixed-use developments: A critical realist's perspective. Paper in 20th Annual Pacific-Rim Real Estate Society Conference, Christchurch, New Zealand.

[4] Coupland, A. (1997). Reclaiming the City: Mixed use development, Routledge.

[5] Grant, J. (2002). Mixed use in theory and practice: Canadian experience with implementing a planning principle. Journal of the American Planning Association, 68(1): 71-84. 10.1080/01944360208977192

[6] Rhind, D. (1980). Land Use. New York: Mc Graw Hill.

[7] Croucher, K., Wallace, A., Duffy, S. (2012). The influence of land use mix, density and urban design on health: A critical literature review. University of York, New York.

[8] Murrain, P. (1993). Urban expansion: Look back and learn. Making Better Places: Urban Design, Oxford, JCUD.

[9] Adelaide City Council, Guide to Mixed-use Development, Adelaide City Council, Adelaide, 2009. https://www.academia.edu/37131571/ACC_DIGS_mixe d_use_development_guide accessed on April 14, 2021.

[10] Delhi Development Authority, Master Plan Delhi 1962, New Delhi: Delhi Development Authority, 1962. https://fdocuments.in/document/delhi-master-plan1962.html, accessed on April 14, 2021.

[11] Mahajan, M. (2018). Master planned mixed-use: Lessons from Delhi. Tekton, 5(2): 8-19.

[12] Moudon, A.V., Lee, C., Cheadle, A., Garvin, C., Johnson, D., Schmid, T., Weathers, R., Lin, L. (2006). Operational definition of walkable neighborhood: Theoretical and empirical insights. Journal of Physical Activity and Health, 3: 99-117. https://doi.org/10.1123/jpah.3.s1.s99

[13] Grant, J. (2002). Mixed-use in theory and practice: Canadian experience with implementing a planning principle. Journal of American Planning Association, 68(1): 71-84. https://doi.org/10.1080/01944360208977192

[14] Yue, W., Chen, Y., Zhang, Q., Liu, Y. (2019). Spatial explicit assessment of urban vitality using multi-source Data: A case of Shanghai, China. Sustainability, 11(3): 638. https://doi.org/10.3390/su11030638

[15] Punter, J. (1991). Participation in the design of Urban Space. Landscape Design, 200, 24-27.

[16] Nabil, N.A., Abd Eldayem, G.E. (2015). Influence of mixed land-use on realizing the social capital. HBRC Journal, 11(2):

285-298. https://doi.org/10.1016/j.hbrcj.2014.03.009

[17] Bahadure, S., Kotharkar, R. (2015). Assessing sustainability of mixed use neighbourhoods through residents' travel behaviour and perception: The case of Nagpur, India. Sustainability, 7(9): 12164-12189. https://doi.org/10.3390/su70912164

[18] Ghosh, P. (2017). Mixed landuse practices and implications. International Journal of Scientific Development and Research, 2(9): 1-8.

[19] Cervero, R. (2007). Transit-oriented development's ridership bonus: A product of self-selection and public policies. Environment and Planning A: Economy and Space, 39(9): 2068-2085. 
[20] Delhi Development Authority, Master Plan Delhi 2001, New Delhi: Delhi Development Authority, 2001. http://119.226.139.196/ddaweb/planning.aspx, accessed on April 14, 2021.

[21] Delhi Development Authority, Master Plan Delhi 2021, New Delhi: Delhi Development Authority, 2021. http://119.226.139.196/ddaweb/planning.aspx, accessed on April 14, 2021.

[22] CPHEEO, Manual on Water Supply, 2nd edition, Delhi: Ministry of Urban Development, 1990. http://cpheeo.gov.in/cms/ manual-on-water-supply-andtreatment.php, accessed on April 14, 2021.

[23] Central Pollution Control Board, Status of Ambient Noise Level in Delhi, Central Pollution Control Board, Delhi, 2006. https://cpcb.nic.in/archivereport.php, accessed on April 14, 2021.

[24] Central Pollution Control Board, Air quality monitoring, emission inventory and source apportionment study for
Indian cities, Central Pollution Control Board, New Delhi, 2011. https://cpcb.nic.in/source-apportionmentstudies/, accessed on April 14, 2021.

[25] Ministry of Urban Development (Delhi Division), «The Gazette of India, Notification, No.-1493», New Delhi, 2015.

https://cpcb.nic.in/displaypdf.php?id=RmluYWxOYXR pb25hbFN1bW1hcnkucGRm, accessed on April 14, 2021.

\section{NOMENCLATURE}

sq. m. area in square metres sq. yd. area in square yards $\mathrm{Kg} \quad$ weight in kilograms L volume in litres 